\title{
Relapsing polychondritis detected in PET/CT
}

\author{
Rafal Czepczyński • Izabela Guzikowska-Ruszkowska • \\ Anna Wyszomirska
}

Received: 6 February 2012 / Accepted: 20 March 2012 /Published online: 20 April 2012

(C) The Author(s) 2012. This article is published with open access at Springerlink.com

We report a case of relapsing polychondritis (RP) in a patient in whom PET/CT using ${ }^{18} \mathrm{~F}$-FDG performed due to a suspicion of malignancy led to the diagnosis of RP.

A previously healthy man, aged 57 years, was admitted to hospital for the diagnosis of chronic fever and weight loss of about $5 \mathrm{~kg}$. Extensive laboratory and imaging evaluation showed only elevated C-reactive protein levels up to $180 \mathrm{mg} / \mathrm{l}$ (normal value $<10 \mathrm{mg} / \mathrm{l}$ ) and erythrocyte sedimentation rate up to $118 \mathrm{~mm} / \mathrm{h}$. Endoscopic evaluation showed signs of chronic laryngitis and sinusitis, oesophageal candidiasis, chronic gastritis and a benign sigmoid polyp. Antibacterial and antifungal therapy did not cause any significant improvement in the fever or laboratory findings.

R. Czepczyński • I. Guzikowska-Ruszkowska • A. Wyszomirska Department of PET/CT, Euromedic Diagnostics,

Poznań, Poland

R. Czepczyński • A. Wyszomirska

Department of Endocrinology and Metabolism,

Poznan University of Medical Sciences,

Poznań, Poland

I. Guzikowska-Ruszkowska

Department of General Radiology,

Poznan University of Medical Sciences,

Poznań, Poland

R. Czepczyński ( $\bowtie)$

Department of Endocrinology,

Poznan University of Medical Sciences,

Przybyszewskiego 49,

PL-60-355 Poznań, Poland

e-mail: rafal.czepczynski@euromedic.pl
PET/CT using ${ }^{18}$ F-FDG showed diffuse ${ }^{18}$ F-FDG accumulation in all costal cartilages and in the sternal angle $\left(\mathrm{SUV}_{\max }=4.5\right)$. Additionally, symmetrically increased ${ }^{18} \mathrm{~F}$ FDG activity in the joints of the upper extremities (elbows and wrists) was found. A moderately increased ${ }^{18} \mathrm{~F}-\mathrm{FDG}$ concentration in the hypopharynx was also visible. The CT scan demonstrated thickened tracheal mucosa that did not show any ${ }^{18} \mathrm{~F}-\mathrm{FDG}$ activity. The characteristic complex of signs and symptoms after exclusion of malignancy led to the diagnosis of RP - a rare autoimmune disease characterized by inflammation of cartilaginous tissues of the larynx, trachea and ears [1-3].

The patient was treated with glucocorticosteroids that provided rapid improvement of the symptoms and laboratory parameters.

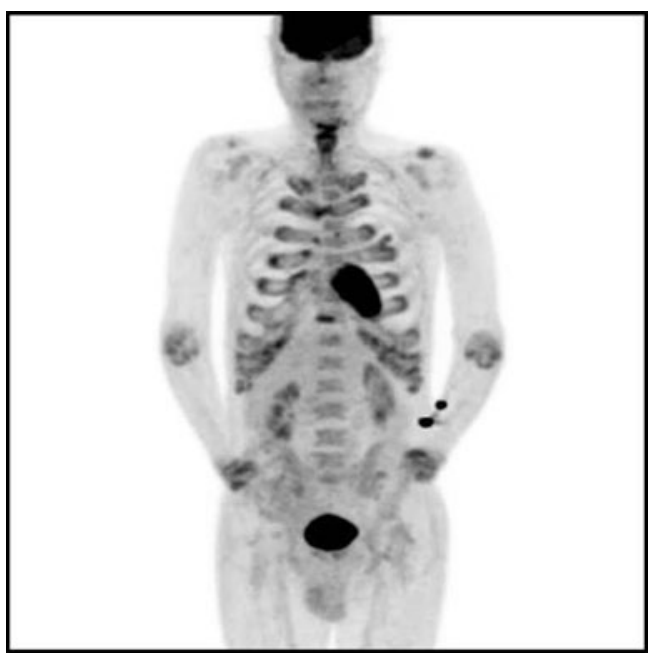




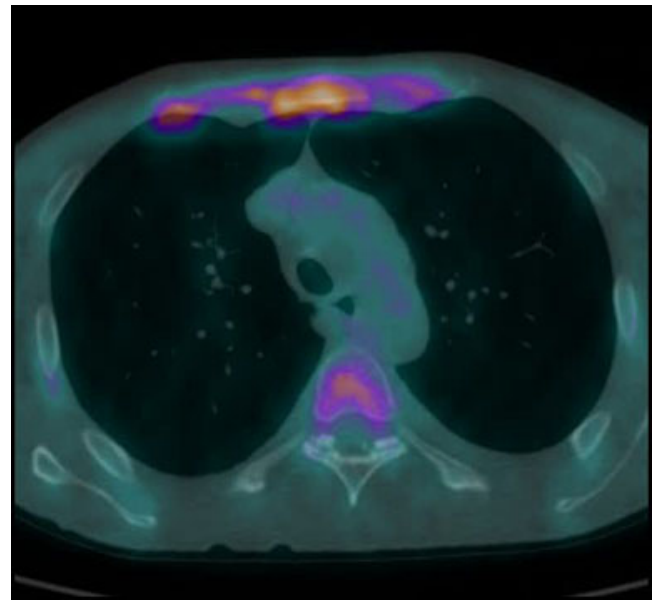

Open Access This article is distributed under the terms of the Creative Commons Attribution License which permits any use, distribution, and reproduction in any medium, provided the original author(s) and the source are credited.

\section{References}

1. De Geeter F, Vandecasteele SJ. Fluorodeoxyglucose PET in relapsing polychondritis. N Engl J Med. 2008;358:536-7.

2. Sato M, Hiyama T, Abe T, Ito Y, Yamaguchi S, Uchiumi K, et al. F-18 FDG PET/CT in relapsing polychondritis. Ann Nucl Med. 2010;24:687-90.

3. Gergely Jr P, Poor G. Relapsing polychondritis. Best Pract Res Clin Rheumatol. 2004;18:723-38. 